\title{
In dedication to Doğan Taner (1930-2021)
}

\author{
Deniz Demiryürek (D) \\ Department of Anatomy, Faculty of Medicine, Hacettepe University, Ankara Turkey \\ Anatomy 2021;15(1):91-94 (2021 Turkish Society of Anatomy and Clinical Anatomy (TSACA)
}

This article is dedicated to the memory of Prof. Dr. Doğan Taner, the former Dean of Hacettepe University Faculty of Medicine and the head of Department of Anatomy, who passed away on March 12, 2021 in Ankara. He was one of the greatest clinical anatomist many of us are familiar with. It was not only my personal, but also all Turkish Anatomists' grief to learn the decease of Prof. Dr. Doğan Taner.
His contributions to medical education, clinical anatomy and personal supports to the development of academic career of many Turkish anatomists, including myself, will never be forgotten. I had the honor of being a research assistant to him and working together with, at the beginning of my academic life, which was a great privilege.

He was a wonderful mentor, a very knowledgeable person and an irreplaceable figure in Anatomy worldwide. He

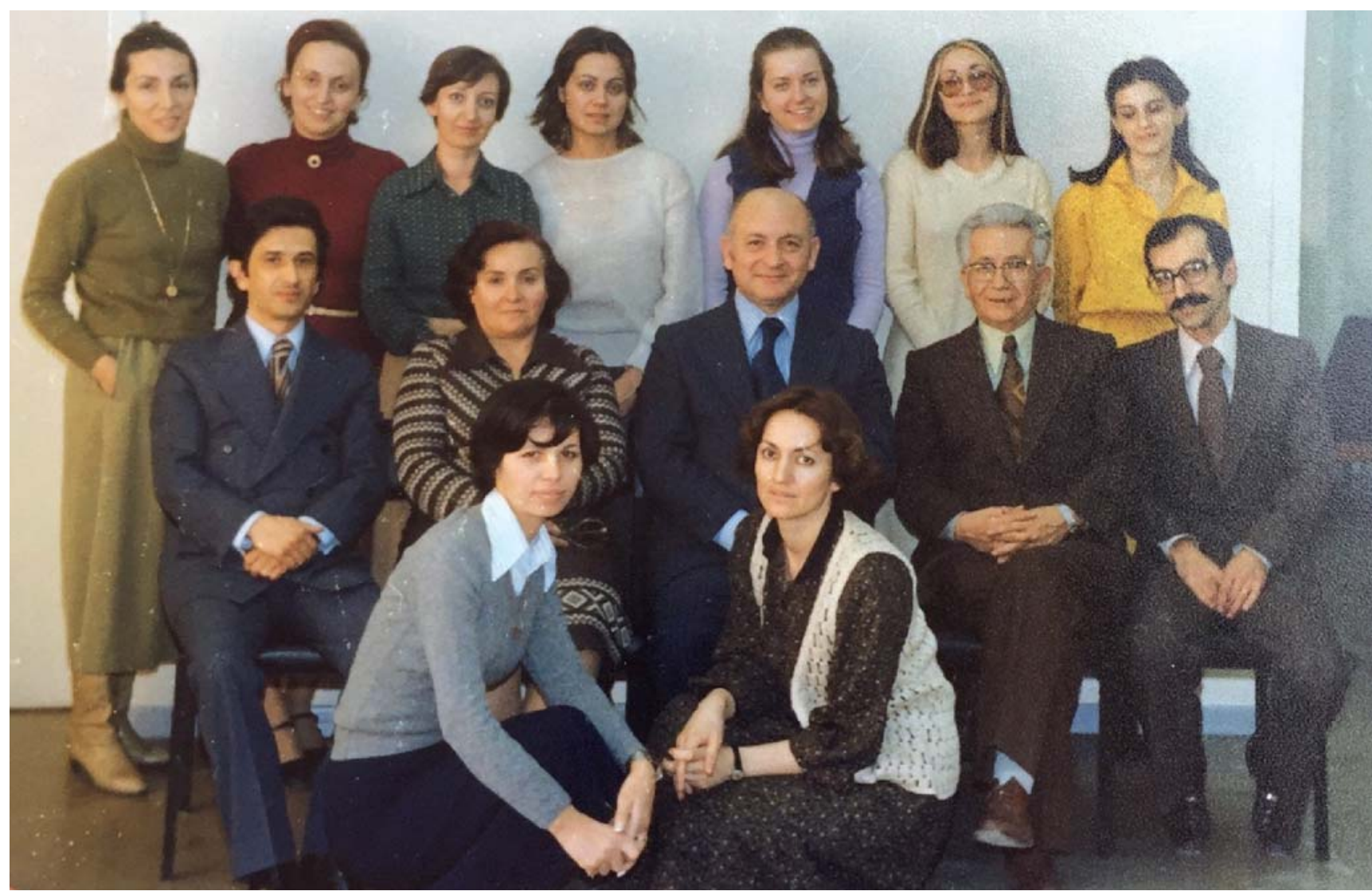

Figure 1. Hacettepe Anatomy Family, 2019, Ankara. From left to right, upper row: Seza Arbay, Kübra Yıldırım, Beliz Taşçığlu, Emine Özkul, Ergül Ersoy, Tülin Aras; middle row: Doğan Akşit, Bedia Sancak, Doğan Taner, Sıddık Karatay, Sezgin llgi; lower row: Nuran Yener, Meserret Cumhur. 
was also one of the honorary members of the Turkish Society of Anatomy and Clinical Anatomy. That is one of the several reasons why I wanted to write this article for his memory. You will have chance to read and learn more about him in this article.

Dr. Doğan Taner was born in Cyprus in 1930. After completing his primary, secondary and high school education in Cyprus, he started his medical education in İstanbul University Faculty of Medicine and graduated as a medical doctor in 1955 .

He started his residency program in cardiology at New York Medical College, New York City, United States in 1955 and received his degree in 1960. He worked as a cardiologist at West Hendon Hospital-London and London University St. John's Hospital between 1960 and 1963. Since he was born in Cyprus, he joined the academic staff of Hacettepe University Faculty of Medicine as a foreign lecturer in 1964. He received his Associate Professor title in the Department of Anatomy and after being a Turkish citizen, he received his Professor of Anatomy title in 1971.

Prof. Dr. Doğan Taner was one of the founders of Department of Anatomy at Hacettepe University Faculty of Medicine and he was the head of the department for so many years until his retirement. Additionally, during his professional life at Hacettepe University, Dr. Taner worked as the faculty's Phase 2 medical students coordinator (1965-1966, 1969-1971), Director of Medical Technology High School (1967-1971), General Secretary of Institute of Population Studies (1971-1972), Chief

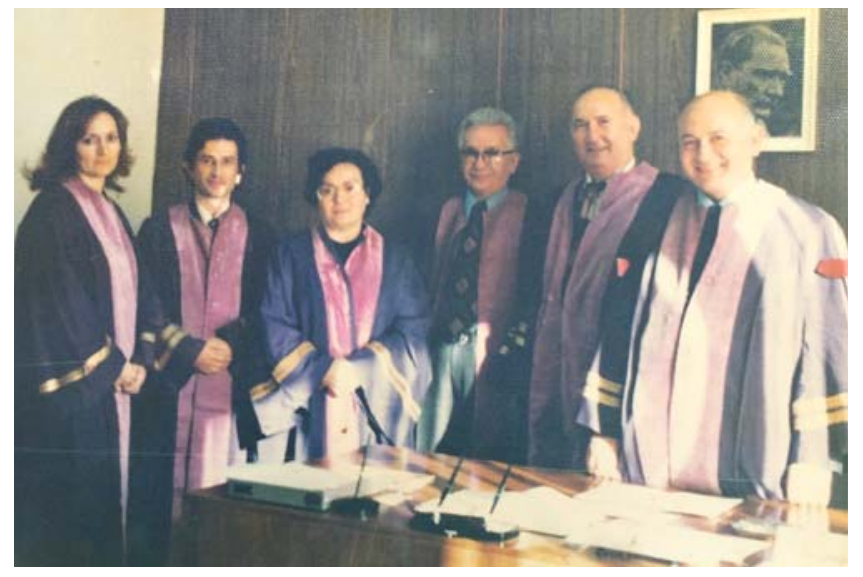

Figure 2. The board of "Associate Professor Academic Title". From left to right: Meserret Cumhur, Doğan Akşit, Bedia Sancak, Sıddık Karatay, Ilhan Eralp, Doğan Taner.

Coordinator of Medical Education (1971-1981), Director of Institute of Modern Lingustics (1973-1974), Head of Basic Medical Sciences (1973-1981, 1994-1997), Dean of Health Sciences Faculty (Medicine and Health Sciences Post Graduation Education Faculty) (1975-1981), Dean of Faculty of Medicine (1982-1991) and Editor of Hacettepe Medical Journal (1983-1991).

Dr. Taner was one of the founders of Association of Medical Education in Europe and worked as an advisory board member between 1972 and 1994. He also worked as General Secretary of Education Council of Medical and Health Sciences of Turkish Universities (1978-

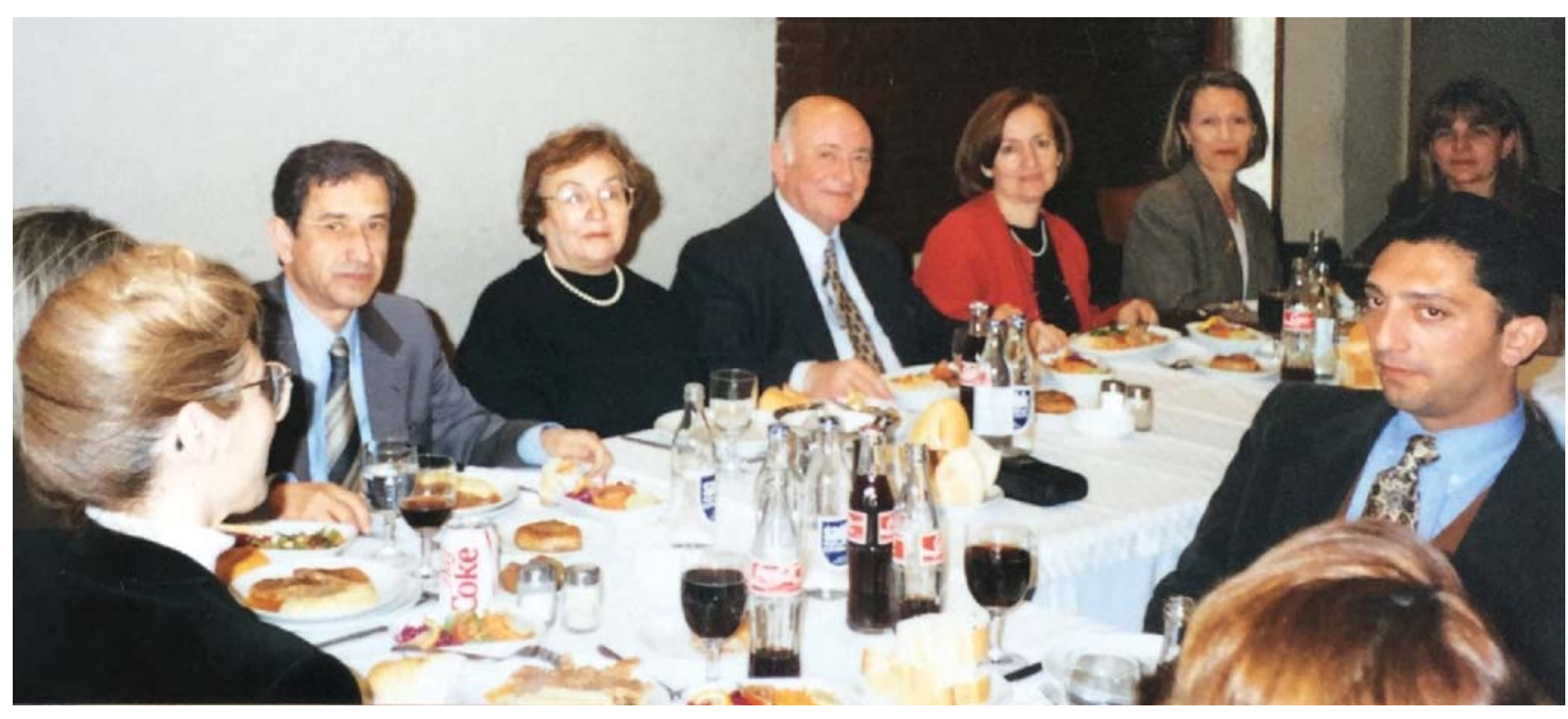

Figure 3. New year party, 1994, Ankara. From left to right: Nuran Yener, Doğan Akşit, Bedia Sancak, Doğan Taner, Meserret Cumhur, Engin Kural, Selda Önderoğlu, Alper Atasever. 
1994), one of the founders of Turkish Medical Education Presidential (1984-1994), Executive Committee member of Association of Medical Deans in Europe (1990-1993), Membership of The Scientific and Technological Research Council of Turkey-Scientist Education Group (1991-1993), Membership of Interuniversity Board Associate Professor Ethics Board (2002-2004). In 1997 Dr. Taner was appointed as the advisor of President of Higher Education Council.

Prof. Dr. Doğan Taner worked as a consultant for World Health Organization in 1972 and 1976. At several meetings in the field of medical education, he represented his university and country at European Council, OECD and ECFMG many times.

His scientific fields of interest were clinical anatomy and medical education. After a lot of effort and hard work, he founded the first ever-English Faculty of Medicine in Turkey. He also applied the systematic committee learning system in medical education instead of classical medical education, which was a great innovation for Turkey in the field of medicine.

Not only was many international publications, Dr. Taner also the editor of two books; Functional Anatomy and Functional Neuroanatomy. In July 22, 1997 Prof. Dr.
Doğan Taner retired from Hacettepe University after many years of productivity and hard work. He was married to Gudrun Taner for 55 years and they had two daughters, Deniz and Aylin.

He attended the meetings of international associations frequently, also won prizes for 'Medical education'. He remained memorable for his style of lectures, presenting with an easiness and high standard. During his lectures, he used to use a pointer for choosing a student, and then he would ask his questions about the lecture to the student behind or next to him, so that he could keep the attention on the lecture until the end of time.

When I saw him as a presenter for the first time at a lecture of neuroanatomy of at Hacettepe in 1996, I was deeply moved and impressed by the manner of his presentations, the standard and the clinical background of his scientific work. He became an idol for me, to work hard and to my best in presenting our scientific work on national and international platforms. Moreover, he was a respected person with high reputation at that time. In addition, he always highlighted the affiliation to the University of Hacettepe and was proud to be part of the department and faculty. All the upcoming years, he surprised everyone with new investigations and never rested to support young

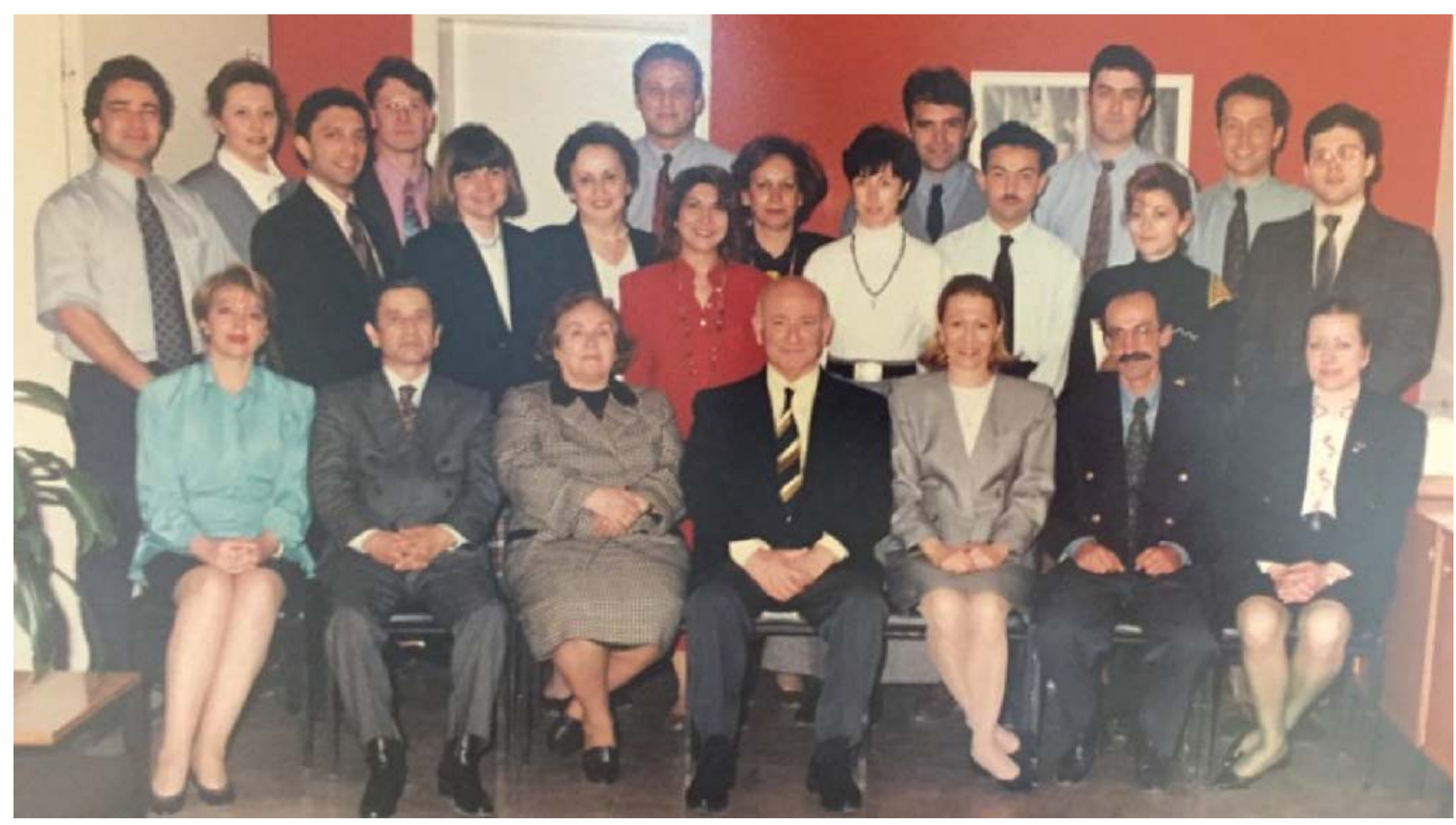

Figure 4. Hacettepe Anatomy Family, 1992, Ankara. From left to right; upper row: Hakan Öztürk, Mine Ergun, Alper Atasever, Cem Denk, Selda Önderoğlu, Emine Özkul, Mustafa Aldur, Mürvet Tuncer, Demet Zağyapan, Selçuk Sürücü, Mustafa Sargon, Barbaros Durgun, Hamdi Çelik, Engin Yılmaz; lower row: Ruhgün Başar, Doğan Aksit, Bedia Sancak, Doğan Taner, Engin Kural, Sezgin Ilgi, Beliz Taşçıoğlu. 
colleagues not only from our department, such as myself, but especially encouraged young scientists to come to Hacettepe. Many visits were enforced by Prof. Taner's support; many of us, nowadays-experienced scientists still remember unforgettable memories at Hacettepe.

The importance of the clinical aspects of anatomy and teaching anatomy in medical field always remained a priority in Professor Taner's scientific and academic career. For him, science was the most important part of the anatomist's work. He always encouraged us for publishing articles in international journals with high impact factors and followed our progress. It was not only a great motivation for us, but also an effective control system of our studies.

Teaching was also the other important part. I was lucky to be able to assist him in his lectures for many years. He was one of the professors, who was able to present almost any topic of the human body without any prior preparation. He was using slides of the anatomical atlases spontaneously during the lecture and he had a wonderful memory about the anatomical details present inside the slide contents.

All his work, his love to study and to teach was alive in him until the very end. He would read anatomy from the latest edition of Gray's during the nights and the day after, would ask us questions from the things he read the previous night. Although he retired after working so many years in the field of medical and anatomy education, I often took his advice due to his experience and passion for Anatomy. The passion and his spirit influenced so many of us and encouraged us in becoming a better teacher, better scientist and better anatomist daily.

Professor Taner; thank you for all moments; thank you for the time we could share together; thank you for being a personal highlight and unforgettable professor of our anatomical community. Your vision and multifaceted work will remain alive in all of us, to inspire us and therefore extend its light to so many generations to come.

\section{Acknowledgement}

Please see video supplemental content, https://drive. google.com/file/d/1c5Dp_9QcHux5cAv9Ma82VYER8T $\mathrm{KZ1xH7/view?usp=sharing;} \mathrm{which} \mathrm{shows} \mathrm{the} \mathrm{speech} \mathrm{of}$ Prof. Bülent Altun (Dean of Hacettepe University Faculty of Medicine) and https://drive.google.com/file/d/1GH2z2_tgj5VLRXKEhMbfmWPleUe7bIp/view?usp=sh aring; which shows the speech of Deniz Taner Gökçe (elder daughter of Prof. Doğan Taner).
ORCID ID:

D. Demiryürek 0000-0001-8781-1719
Correspondence to: Deniz Demiryürek, MD, PhD

Department of Anatomy, Faculty of Medicine, Hacettepe University, 06100, Sihhiye, Ankara, Turkey

Phone: +903123052359

e-mail:mdeniz@hacettepe.edu.tr

Conflict of interest statement: No conflicts declared.

This is an open access article distributed under the terms of the Creative Commons Attribution-NonCommercial-NoDerivs 3.0 Unported (CC BY-NCND3.0) Licence (http://creativecommons.org/licenses/by-nc-nd/3.0/) which permits unrestricted noncommercial use, distribution, and reproduction in any medium, provided the original work is properly cited. Please cite this article as: Demiryürek D. In dedication to Doğan Taner (1930-2021). Anatomy 2021;15(1):91-94. 